\title{
Пространственное неравенство и накопление человеческого капитала в Европейской России при переходе к «современному» типу экономического роста (конец XIX - начало XX в.) ${ }^{1}$
}

\author{
Д.В. ДИДЕНКО*
}

\begin{abstract}
*Дмитрий Валерьевич Диденко - доктор экономических наук, кандидат исторических наук, ведущий научный сотрудник, профессор, Российская академия народного хозяйства и государственной службы при Президенте Российской Федерации. Адрес: 119571, Москва, проспект Вернадского, д. 82, стр. 1. E-mail: didenko-dv@ranepa.ru
\end{abstract}

Цитирование: Диденко Д.В. (2021) Пространственное неравенство и накопление человеческого капитала в Европейской России при переходе к «современному» типу экономического роста (конец XIX - начало XX в.) // Мир России. Т. 30. № 3. С. 100-126. DOI: $10.17323 / 1811-038 X-2021-30-3-100-126$

В статье анализируются вопросы межрегиональной дифференциации в накоплении человеческого капитала в России при переходе к индустриальному развитию в дореволюциионный период. В качестве основного источника статистических данных о финансировании сфер образования и здравоохранения используются годовые губернаторские отчеты. Применяются модели динамики пространственного неравенства С. Кузнеияа (кривая в виде обратной буквы U), Р. Барро и Х. Сала-и-Мартина ( $\beta$-конвергенция и б-конвергенция).

Установлено, что в рассматриваемый период происходило относительное сближение в уровнях охвата образованием и в объемах его финансирования; в то же время наблюдались слабовыраженные противоположные прочессы по объему финансирования одного учащегося и по основным показателям в сфере здравоохранения (обеспеченности населения медицинским персоналом, объемам финансирования). Особое внимание уделено роли центрального правительства и органов местного самоуправления в сглаживании межрегиональных различий. Найдень новые свидетельства в отношении повышенной роли изентрального правительства в накоплении человеческого капитала, подтвержда-

\footnotetext{
1 Исследование выполнено в рамках государственных заданий ФГБОУ ВО РАНХиГС, НИР «Вызовы и условия экономического развития регионов Европейской России, Сибири и Дальнего Востока в XIX - начале $\mathrm{XX}$ в.: природная среда, технологии и ресурсы» и «Сравнительная динамика экономического развития регионов в XIX - начале XX в.: Европейская Россия, Сибирь и Дальний Восток».
} 
ющчие концепциию А. Гершенкрона об особенностях социильно-экономического развития в «отставших» странах, осуществлявших догоняющую модернизацию.

Ключевые слова: региональное развитие, конвергенция, дивергенция, губернаторские годовые отчеты, государственные финансы, образование, здравоохранение

\section{Введение}

Рассматриваемый хронологический период, охватывающий конец XIX - начало $\mathrm{XX}$ в. (до начала Первой мировой войны), занимает важное место в процессах социально-экономической модернизации России. В классификации В. Ростоу он включает в себя стадию «переходную к взлету» (от «традиционного общества») и, частично, стадию «взлета», которая получила продолжение в советской ускоренной индустриализации конца 1920-1930-х гг. [Ростоу 1961, с. 99-156]. С. Кузнец характеризовал период с 1860 по 1913 г. как единую стадию «предсовременного роста» России [Kuznets 1966, pp. 63-69]. На основе его методологии П. Грегори относил начало перехода России к «современному экономическому росту ${ }^{2}{ }^{2}$ середине 1880-х гг., при этом период с 1861-1863 гг. по 1881-1883 гг. выделялся им как «ранний», в отличие от «развитого» с 1889-1892 г. по 1901-1904 гг. [Грегори 2003, c. 23-25, 61-63]. Таким образом, в рамках рассматриваемого большого периода, можно выделить две стадии: 1) непосредственная подготовка к запуску современного экономического роста после проведения модернизирующих буржуазных реформ - отмены крепостного права в 1861 г., земской реформы 1864 г. $(1860$ - середина $1880-$ х гг.); 2) ранняя стадия современного экономического роста - середина 1880-х - 1914 г. (до начала Первой мировой войны).

Достаточно обширная исследовательская литература на примерах накопления физического и финансового капитала подтверждает концепцию А. Гершенкрона о типологических особенностях экономического развития в «отставших» странах, осуществляющих догоняющую индустриальную модернизацию [Гершенкрон 2015]. В значительно меньшей степени это касается примеров в структуре и тенденциях накопления человеческого капитала, на которых мы фокусируемся в данной статье.

Развивая первые результаты проекта по реконструкции социально-экономического развития регионов России в дореволюционный период [Didenko 2019], мы непосредственно анализируем вопрос о тенденциях динамики пространственного неравенства (конвергенции и дивергенции) на расширенной выборке губерний. Из 50 губерний, относившихся к Европейской России, мы исключили губернии со столичными городами и на территориях, присоединенных позднее XVII в. и сравнительно слабо интегрированных в политическую и экономическую структуру страны, выбрав для исследования 15 типичных губерний, принадлежащих к районам с разными природно-хозяйственными типами с точки зрения их географического положения, структуры экономики, правового статуса, полноты данных в губернаторских отчетах.

2 Характеризуется увеличением производительности на основе применения в производстве новых знаний в результате развития науки и образования [Kuznets 1966, pp. 63-66, 81-82, 190, 286-293]. 


\section{Исследования исторической динамики накопления человеческого капитала в научной литературе}

С начала 1990-х гг. в научной литературе усилился интерес к региональным исследованиям в сфере экономического роста, стимулируемый накоплением соответствующих количественных данных и разработкой методов их анализа. Во многих из них отмечалась значимая связь объема выпуска и человеческого капитала. В контексте данной проблематики наблюдения о связи экономической активности и эффективности в регионах с наличием транспортных путей, близостью к крупным рынкам нашли подтверждение в недавнем исследовании К. Дибо и Р. Хиппе [Diebolt, Hippe 2018], охватывающем период с XIX в. до настоящего времени. Другим примером анализа воздействия на долгосрочное развитие регионов Западной Европы со стороны человеческого капитала, измеряемого элементарной грамотностью (около 1880 г.) и охватом начальным и средним образованием (1960-1970 гг.), является работа Г. Табеллини [Tabellini 2010], в которой уровень человеческого капитала выступает контрольной переменной наряду с институциональными ограничениями политической власти (1600-1850 г.) для анализа влияния ценностных ориентаций на средний объем добавленной стоимости на душу населения (середина 1970-х - 2001 г.).

Л. Лау с соавторами [Lau et al. 1993] измеряли человеческий капитал средней продолжительностью обучения. На материале Бразилии 1970-х гг. они установили критический уровень его накопления (повышение с 3 до 4 лет обучения), который приводит к ускорению роста валового регионального продукта отдельных штатов [Lau et al. 1993, pp. 58-61, 65].

Используя данные о средних доходах работников и средней продолжительности их обучения, Ч. Тернер и его соавторы [Turner et al. 2007] оценили частную отдачу на человеческий капитал в отдельных штатах и девяти макрорегионах США на уровне в 11-15\% за год обучения. Их источником служила сравнительно хорошая статистика с 1840 г. (шестая перепись населения).

В работе X. Брейнлиха и соавторов анализируется классическая производственная функция, где присутствуют два фактора производства: физический и человеческий капитал. Последний понимается как характеристика качества рабочей силы. Авторы отмечают, что повышение совокупной факторной производительности (СФП) в регионах имеет более важное значение для обеспечения экономического роста по сравнению с накоплением факторов производства [Breinlich et al. 2014].

В исследовании С. Бедельсдейка и соавторов [Beugelsdijk et al. 2018] о детерминантах СФП в регионах Западной Европы к измерению человеческого капитала применен подход, введенный в восьмой версии Penn World Table [Feenstra et al. 2015]. Данные ограничены 2007 г., но в качестве независимой переменной, влияющей на СФП, включен уровень урбанизации в 1800 г.

Б. ван Леувен и соавторы изучали развитие Китая (до уровня провинций) и СССР (до уровня республик) [Van Leeuwen et al. 2015; Van Leeuwen et al. 2017]. Ими было установлено, что и в СССР, и в Китае рост происходил преимуществен-

\footnotetext{
3 Экспоненцирование произведения средней продолжительности образования на уровень доходности одного года обучения.
} 
но за счет накопления факторов производства, а не за счет повышения эффективности [Van Leeuwen et al. 2015; Диденко 2015].

Макроэкономический анализ влияния развития образования и накопления человеческого капитала на развитие российской экономики был проведен Б.Н. Мироновым [Миронов 1994] за период с середины ХІХ в. до конца 1980-х гг. и У. Истерли и С. Фишером [Easterly, Fischer 1995] за период 1960-1989 гг. В обоих исследованиях для характеристики человеческого капитала использовались натуральные показатели - средняя продолжительность обучения (в первом); охват средним образованием и доля специалистов с высшим образованием в общей численности населения (во втором).

В монографии Д.В. Диденко [Диденко 2015] с использованием стоимостных оценок объема человеческого капитала были идентифицированы долгосрочные тенденции и наиболее важные закономерности его накопления и использования в советский и постсоветский периоды. При этом дореволюционный период был им рассмотрен лишь эпизодически.

В исследовании А.В. Суворова и соавторов [Суворов и др. 2016] проведен расчет объема человеческого капитала российской экономики и отдельных ее отраслей за период 1991-2012 гг. методом накопленных затрат (годовых расходов на образование и здравоохранение в постоянных ценах за период с начала 1920-х гг.) по аналогии с показателями физического капитала. Затраты на здравоохранение, относившиеся только к рабочей силе, оказались близкими к экспертной оценке Дж. Кендрика в 50\% [Кендрик 1978, с. 49].

Квантитативные исследования с использованием показателей человеческого капитала в период Российской империи [Миронов 2014-2015; Cheremukhin et al. 2017] дают опорные точки для их продолжения на региональном уровне. Так, на примерах отдельных регионов Европейской России было продемонстрировано, какую роль играли институциональные сектора экономики в финансировании образования и здравоохранения как основных сфер формирования человеческого капитала [Didenko 2019].

Проведенный нами анализ научной литературы показывает, что более распространенным для исследования человеческого капитала в период раннеиндустриальной экономики является использование показателей элементарной и количественной грамотности, охвата населения начальным (реже средним) образованием. Однако статистические данные, дающие основания для расчетов стоимостных оценок объема человеческого капитала на основе затрат, начинают появляться только с конца XIX в.

Актуальной научной проблемой остается изменение во времени межрегионального неравенства. В исследовании К. Дибо и Р. Хиппе [Diebolt, Hippe 2017] оно измерялось индексом Джини и коэффициентом вариации указанных показателей, взвешенных по численности населения. Согласно выводам данного исследования, историческая инерция в Европе проявляется на региональном уровне даже в большей степени, чем на страновом.

Конвергенция регионов Италии по уровню человеческого капитала, которая происходила в основном в период 1910-1960-х гг, рассматривалась в работе Э. Феличе [Felice 2012]. В условиях слабой доступности данных для расчета объема человеческого капитала он построил индекс, включавший данные о грамотности и количестве учащихся в разных уровнях образования. 
Веса составляющих индекса менялись во времени так, чтобы отразить смещение в сторону более высоких уровней на поздних стадиях индустриального развития [Felice 2012, pp. 275-277].

Ч. Тернер и соавторы [Turner et al. 2013] использовали полученные ранее данные о средней продолжительности обучения в производственной функции для оценки факторов производства (человеческий, физический капитал, земля) и их совокупной производительности в процессе конвергенции штатов по уровню доходов (зависимая переменная). Было установлено, что на $70 \%$ процесс конвергенции в объеме выпуска в штатах США определялся их сближением в СФП.

Согласно выводам Й. Батена и его соавторов [Baten, Hippe 2018; Crayen, Baten 2010; Baten et al. 2017], неравенство в уровне количественной грамотности во многом объясняет различия в темпах роста благосостояния, в частности в выборке 25 штатов США в раннеиндустриальную эпоху. Ими также анализировалось (посредством линейной регрессии) воздействие факторов, влиявших на количественную грамотность (зависимая переменная), в целом по Центральной и Восточной Европе, а также в Тульской и Вятской губерниях Российской империи [Baten et al. 2017, pp. 43-51].

Осуществленные А. Маркевичем [Markevich 2018] на основе региональных данных за 1897 г. расчеты валового регионального продукта (ВРП) дают понимание того, что в Российской империи межрегиональное неравенство было достаточно высоким, сопоставимым по уровню с межстрановым неравенством в то время. В период с 1897 по 2014 г. наблюдалась конвергенция, и ее темп примерно соответствовал темпам межстрановой в Западной Европе, но отставал от внутристрановой в США и Западной Европе. Возникает вопрос: началась ли она в советский период или уже наблюдалась в дореволюционный?

\section{Используемые данные источников}

В постсоветской литературе отмечается, что губернаторские отчеты имеют высокий информационный потенциал [Бражникова 2013, с. 83-89] и являются ценным источником по изучению состояния медицины и образования [Кискидосова 2016, с. 52]. А.А. Ярцев обращает внимание, что фактическое рассекречивание содержания губернаторских отчетов, публикация их статистической части способствовали повышению ответственности губернаторов за достоверность их сведений, при этом возможность прямой фальсификации практически исключалась; объективность информации оценивается как более высокая в отношении пореформенного периода по сравнению с предыдущим [Яриев 2015, с. 17, 20, 24]. Что касается непосредственно проблематики человеческого капитала, то в начале 1960-х гг. Н.П. Дятлова писала в позитивном контексте относительно отражении в губернаторских отчетах сведений о развитии народного образования и здравоохранения за период 1837-1916 гг., однако она воздерживалась от прямой оценки степени их достоверности [Дятлова 1964, с. 238, 243].

Сведения из губернаторских отчетов выборочно сопоставлялись нами с опубликованными данными (основанными на ведомственной статистике за отдельные годы) по государственному финансированию в региональном разрезе 
[Яснопольский 1897] ${ }^{4}$ и дополняющей их земской статистикой [Бычков 1894; Статистический временник Российской империи 1886, с. 56-57; Шараго 1914, c. 398-411, 432-433, 458-459], а также набором данных [Кесслер, Маркевич 2014-2019] со срезом за 1897 г. Результаты сопоставлений показывают, что достоверность содержащейся в губернаторских отчетах информации об образовании и здравоохранении может быть оценена как приемлемая.

\section{Методология анализа}

Применение концептуального аппарата теории человеческого капитала к исследованию динамики сфер образования и здравоохранения при запуске и на ранних стадиях «современного экономического роста» релевантно, поскольку происходившие в них изменения существенно влияли на генезис индустриального общества, генерировали и распространяли вширь кардинальные изменения экономических институтов в капиталистическом (но не обязательно в рыночном) направлении.

На этом этапе развития в социальной, экономической и финансовой системах закономерно увеличивались структурные дисбалансы. В частности, имеются свидетельства, что уровень индивидуального неравенства доходов возрастал на ранних стадиях индустриального развития, как и на ранних стадиях аналогичных крупных системных трансформаций («кривая С. Кузнеца» в виде перевернутой буквы $\mathrm{U}^{5}$ ) вследствие сдвигов в структуре спроса/предложения навыков и в институтах рынков труда. Таким образом, неравномерность развития модернизационных процессов на разных территориях (в частности, урбанизации) должна была закономерно вести к усилению неравенства в формировании человеческого капитала. Из этого следует гипотеза, что в России предреволюционного периода наблюдалось увеличение пространственной дифференциации в процессах накопления человеческого капитала и в уровнях нематериального благосостояния. С другой стороны, в рамках единого государства всегда действуют интеграционные тенденции, и любая политическая власть стремится, насколько это возможно, обеспечить единство экономического пространства на подконтрольной ей территории, собирая и перераспределяя финансовые ресурсы в соответствии с характерным для того или иного исторического времени пониманием целевых ориентиров. Хотя апогей такой политики пришелся на XX в., соответствующие императивы отчетливо проявлялись и в XIX в.

Концепция «преимуществ отсталости» [Гершенкрон 2015] содержит положение о повышенной роли государства в странах «догоняющего развития». Во многих странах поздней индустриализации государство старается заместить прямыми интервенциями нехватку капитала и инфраструктуры, в результате чего капитализм в таких полупериферийных странах второго эшелона характеризуется многими исследователями как «государственный». Применительно к индустриализации России и накоплению физического капитала А. Гершенкрон утверждал: «Главным

\footnotetext{
4 Данные приводятся только по образованию; по здравоохранению отсутствуют.

5 Впервые сформулирована в [Kuznets 1955]. Обобщение эмпирических исследований с использованием исторических данных и модифицированная версия модели С. Кузнеца предложены в [Didenko 2012].
} 
стратегическим фактором обеспечения капиталом в России следует назвать государственную бюджетную политику, хотя в стране имелись и другие источники» [Гершенкрон 2015, с. 112]. А. Гершенкрон не являлся сторонником концепта «человеческий капитал», и вопросы его формирования не получили в его трудах значительного освещения. Допуская операционализацию понятия «отсталость» уровнем грамотности населения, он в большей мере делал акцент на возможностях заимствования знаний и квалифицированных кадров, чем институтов формирования человеческого капитала [Гершенкрон 2015, с. 113, 440, 445-446].

Для анализа динамики пространственного неравенства Р. Барро и X. Сала-и-Мартин ввели понятия $\sigma$-конвергенции и $\beta$-конвергенции [Барро, Сала-и-Мартин 2010, с. 591-593]. Согласно их концепции, понижение пространственной дифференциации абсолютных значений показателей ( $\sigma$-конвергенция) происходит, прежде всего, за счет опережающих темпов их изменений в отстающих сегментах ( $\beta$-конвергенция). Механизмами сокращения пространственной дифференциации выступают централизованные бюджетные трансферты, реаллокация государственных и частных инвестиций, миграция рабочей силы (с пониженным запасом человеческого капитала в более обеспеченные регионы и с его повышенным запасом в менее обеспеченные). Таким образом, снижение пространственной дифференциации (конвергенция) может свидетельствовать о преобладании интеграционных тенденций. В то же время ее усиление (дивергенция) интерпретируется как тенденция к дезинтеграции определенной территориально-государственной общности или межгосударственного объединения.

\section{Насколько быстро шло накопление человеческого капитала?}

C точки зрения теории человеческого капитала затраты на финансирование образования и здравоохранения представляют собой объемы валовых инвестиций на его накопление. В целом по Российской империи уровень совокупных расходов на образование (государственные и негосударственные) в 1885 г. оценивается нами в $0,95 \%$ ВНП, при этом расходы домохозяйств составляли около $25 \%$ совокупных затрат ${ }^{6}$; в 1913 г. (по нашим оценкам) все расходы на образование составляли уже около $2,0 \%$ ВНП ${ }^{7}$.

В период с 1885 по 1913 г. объем финансирования образования в реальном выражении увеличился в 5,1 раза $^{8}$, а с учетом роста численности населения в 1,6 раза [Волков 1930]; подушевой реальный уровень финансирования увеличился примерно в 3,2 раза, при этом количество учащихся возросло в 5,2 раза [Johnson 1950]. Из этого следует, что реальный объем финансирования одного учащегося сохранялся примерно на одном уровне. При столь высоких показателях роста уровня накопления человеческого капитала в России в рассматриваемый период он должен был значительно превышать уровень его выбытия (в связи

\footnotetext{
6 На основе [Kaser 1974, pp. 248-249; Грегори 2003, с. 240].

7 На основе [Грегори 2003, с. 242].

8 Дефлировано по Бюджетному индексу в [Струмилин 1954, с. 514-515] (цит. по: [Проект «Динамика экономического и социального развития России в XIX - начале XX в.»]).
} 
с физической смертью носителей) и амортизации (в связи с моральным устареванием знаний), что должно было привести к увеличению валового и чистого объема человеческого капитала.

Оценив нормы накопления человеческого капитала в Российской империи, мы получили базу для сравнения показателей в регионах с общестрановыми. Рассматривая выборку из 15 губерний Европейской России, можно сравнить показатели регионов в сфере накопления человеческого капитала с аналогичными результатами в целом по Российской империи. В данном случае были использованы агрегированные (валовые) данные, поскольку по большинству губерний на данном этапе отсутствуют достоверные данные по численности населения за достаточное количество лет. Результаты сравнения по Архангельской, Новгородской, Смоленской, Калужской, Пермской, Рязанской губерниям свидетельствуют о том, что темпы роста объема финансирования значительно превышали темпы увеличения численности населения, а различия в темпах накопления человеческого капитала (измеренные коэффициентом вариации) значительно превышали различия в темпах увеличения численности населения. Соответственно, динамика агрегированных данных аппроксимирует изменение относительного положения рассматриваемых регионов с приемлемой точностью.

Темпы накопления человеческого капитала в сфере образования в российских губерниях показаны в таблище 1. Из представленных данных следует, что регионами-лидерами в целом за период с 1870-х гг. по 1913 г. и за отдельные подпериоды стали Вологодская и Пензенская губернии; Рязанская губерния по финансированию сферы образования также устойчиво опережала общестрановую динамику в 1885-1913 гг. В то же время заметное отставание показали Калужская и Курская губернии. При этом темпы роста в отдельные подпериоды могли меняться: губернии, усиленно накапливавшие человеческий капитал в образовании в 1870-х - середине 1880-х гг., впоследствии могли испытать замедление, другие наоборот - ускорить темпы накопления (в соответствии с моделью $\beta$-конвергенции). Так, темпы накопления в Екатеринославской и Новгородской губерниях, характеризовавшиеся незначительными показателями в 1870-е - середине $1880-$ Х гг, впоследствии ускорились; и напротив, Псковская губерния, вслед за быстрым накоплением в 1870-1885 гг., перешла к относительно низким темпам в последующие 25 лет, при этом динамика реального финансирования образования в ряде губерний (Вологодской, Калужской, Пензенской) была довольно неровной.

Возникает вопрос: произошли ли в этой связи изменения в относительном положении регионов с точки зрения накопления человеческого капитала, и если да, то насколько поменялось их положение в относительном рэнкинге? Об этом напрямую свидетельствуют данные таблицьь 2 (см. на стр. 109), демонстрирующие, что изменения в относительном положении регионов по реальному объему финансирования образования в период с 1878 по 1910 г. были достаточно заметными: три региона (Калужская, Курская и Псковская губернии) опустились на три-шесть позиций, в то время как Пензенская губерния поднялась сразу на восемь позиций; без изменений осталась ситуация в Архангельской, Екатеринославской, Пермской губерниях.

Перейдем к другой крупной сфере накопления человеческого капитала - здравоохранению, в которой также наблюдались быстрые темпы расширения финансирования, хотя и с некоторым отставанием от сферы образования. В целом по Российской империи уровень совокупных (государственных и негосударственных) 
расходов на здравоохранение в 1885 г. оценивается нами в 0,9\% ВНП, в 1913 г. в 1,66\% ВНП ${ }^{9}$. При том, что полнота данных по здравоохранению оказалась несколько хуже, чем по образованию, из таблищы 3 (см. на стр. 110) видно, что с 1870-х гг. до начала Первой мировой войны быстрее всего данный процесс шел в Вологодской и Смоленской губерниях, медленнее всего - в Калужской и Рязанской губерниях. Причем в Вологодской, Смоленской и Ярославской губерниях быстрое увеличение финансирования здравоохранения касается раннего пореформенного периода 1870-х - середины 1880-х гг. (до начала современного экономического роста).

\section{Таблица 1. Темпы роста объема финансирования образования в губерниях Европей- ской России в реальном выражении}

\begin{tabular}{|c|c|c|c|c|c|c|}
\hline \multirow{2}{*}{ Территория (губерния) } & \multicolumn{2}{|c|}{ 1870-e - 1913 г. } & \multicolumn{2}{|c|}{$\begin{array}{c}1870-\mathrm{e}- \\
\text { середина } 1880-x \text { гг. }\end{array}$} & \multicolumn{2}{|c|}{$\begin{array}{c}\text { середина } \\
1880-x-1913 \text { г. }\end{array}$} \\
\hline & $\begin{array}{c}\text { В целом за } \\
\text { период, раз }\end{array}$ & $\begin{array}{c}\text { В среднем } \\
\text { за год, \% }\end{array}$ & $\begin{array}{c}\text { В целом за } \\
\text { период, раз }\end{array}$ & $\begin{array}{c}\text { В среднем } \\
\text { за год, \% }\end{array}$ & $\begin{array}{c}\text { В целом за } \\
\text { период, раз }\end{array}$ & $\begin{array}{c}\text { В среднем } \\
\text { за год, } \%\end{array}$ \\
\hline Российская империя & $\mathrm{H} / д$ & $\mathrm{H} / д$ & $\mathrm{H} / д$ & $\mathrm{H} / д$ & 5,46 & 6,25 \\
\hline Архангельская & H/д & Н/д & $\mathrm{H} / д$ & $6,61^{\mathrm{a}}$ & 5,17 & 6,04 \\
\hline Вологодская & 14,80 & $7,15^{\mathrm{b}}$ & $\mathrm{H} / д$ & $7,34^{\mathrm{c}}$ & 6,79 & 7,08 \\
\hline Вятская & 12,14 & 5,84 & 1,98 & 4,67 & 6,12 & 6,68 \\
\hline Екатеринославская & $\mathrm{H} / д$ & н/д & $\mathrm{H} / д$ & $0,30^{\mathrm{d}}$ & 4,17 & 5,23 \\
\hline Калужская & 5,83 & 4,19 & 1,80 & 4,00 & 3,24 & 4,28 \\
\hline Курская & 5,09 & 3,86 & 1,69 & 3,56 & 3,01 & 4,01 \\
\hline Новгородская & 8,51 & 4,99 & 1,13 & 0,81 & 7,48 & 7,45 \\
\hline Пензенская & $19,51^{\mathrm{e}}$ & 9,13 & $\mathrm{H} / д$ & $\mathrm{H} / д$ & 7,87 & 7,64 \\
\hline Пермская & $8,78^{f}$ & 5,44 & 3,15 & $7,95^{\mathrm{g}}$ & 4,07 & 5,14 \\
\hline Псковская & $7,60^{\mathrm{h}}$ & 5,20 & 2,98 & 7,56 & 2,55 & 3,40 \\
\hline Рязанская & 15,95 & 6,65 & 2,51 & 6,32 & 6,36 & 6,83 \\
\hline Саратовская & 10,47 & 5,61 & 1,91 & 4,41 & 5,48 & 6,26 \\
\hline Смоленская & 6,42 & 4,31 & 1,42 & 2,35 & 4,03 & 5,11 \\
\hline Тамбовская & 6,25 & 4,25 & 1,46 & $2,55^{\mathrm{i}}$ & 4,54 & 5,55 \\
\hline Ярославская & 7,53 & 5,31 & 2,74 & 6,95 & 3,51 & 4,58 \\
\hline
\end{tabular}

Рассчитано по: [Kaser 1974, с. 248-249; Грегори 2003, с. 240, 242; Didenko et al. 2013] - по Российской империи; данным губернаторских годовых отчетов [Обзор 1870-1916]; дефлировано по Бюджетному индексу в [Струмилин 1954, с. 514-515] (цит. по: [Проект «Динамика экономического и социального развития России в XIX - начале XX в.»]).

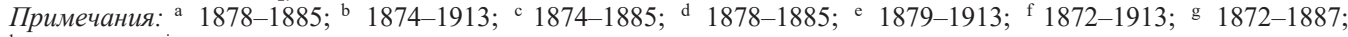
h $1870-1910 ;{ }^{\text {i }} 1885-1910$ 
Таблица 2. Место (ранг) губерний по объему финансирования образования в реальном выражении

\begin{tabular}{|c|c|c|c|c|c|}
\hline \multirow{2}{*}{ Губерния } & \multicolumn{2}{|c|}{ Объемы, руб. 1913 г. } & \multicolumn{2}{|c|}{ Ранги } & \multirow{2}{*}{$\begin{array}{c}\text { Изменение } \\
\text { ранга }\end{array}$} \\
\hline & 1877-1879 гг. & 1910 г. & 1877-1879 гг. & 1910 r. & \\
\hline Архангельская & 66385 & 391420 & 15 & 15 & 0 \\
\hline Вологодская & 396836 & 2284034 & 10 & 9 & 1 \\
\hline Вятская & 768082 & 4368395 & 4 & 2 & 2 \\
\hline Екатеринославская & 1202724 & 4502649 & 1 & 1 & 0 \\
\hline Калужская & 663041 & 2209927 & 7 & 10 & -3 \\
\hline Курская & 712178 & 2083087 & 6 & 11 & -5 \\
\hline Новгородская & 437890 & 2970674 & 9 & 7 & 2 \\
\hline Пензенская & 231262 & 3782091 & 12 & 4 & 8 \\
\hline Пермская & 803185 & 3949065 & 3 & 3 & 0 \\
\hline Псковская & 979822 & 2549645 & 2 & 8 & -6 \\
\hline Рязанская & 334062 & 1597114 & 11 & 12 & -1 \\
\hline Саратовская & 657147 & 3746205 & 8 & 5 & 3 \\
\hline Смоленская & 155753 & 893274 & 14 & 13 & 1 \\
\hline Тамбовская & 713863 & 3546985 & 5 & 6 & -1 \\
\hline Ярославская & 194897 & 871478 & 13 & 14 & -1 \\
\hline
\end{tabular}

Рассчитано по: [Обзор 1870-1916] (данные губернаторских годовых отчетов); дефлировано аналогично таблице 1.

Ускорение процессов накопления человеческого капитала относится скорее к ранней стадии современного экономического роста с середины 1880x по 1913 г., однако в этот период большинство рассматриваемых регионов в большей или меньшей степени отставали от общестрановой динамики. Исключением в выборке является Архангельская губерния, которая заметно опережала другие губернии в сфере здравоохранения (хотя в указанный период в сфере образования это не наблюдалось); медленнее всего финансирование здравоохранения увеличивалось в Псковской и Пензенской губерниях. При этом следует уточнить, что сначала сильно опережающая, а затем сильно отстающая динамика Рязанской губернии может быть обусловлена недостаточным качеством данных в соответствующих губернаторских отчетах.

Данные таблицы 4 (см. на стр. 111) свидетельствуют, что изменения в относительном положении регионов по реальному объему финансирования здравоохранения (в постоянных ценах 1913 г.) за период с 1878 по 1910 г. были наиболее значительными для Ярославской (поднялась на шесть позиций) и Екатеринославской (опустилась на три позиции) губерний. 
Исходя из динамики институциональной структуры финансирования [Didenko 2019, pp. 523-527], можно утверждать, что основным фактором изменений в сфере образования до конца XIX в. было наличие у губернских и уездных земств соответствующих финансовых ресурсов, а в отношении здравоохранения данный фактор являлся определяющим на всем протяжении рассматриваемого периода. По расчетам С. Нафцигера, значимость для земств расходов на образование и здравоохранение сильно выросла: их доля в общей структуре расходов повысилась с 18,1\% в 1871 г. до 63,3\% в 1913 г. [Naftziger 2011, p. 400]. Причем уровень представительства крестьянской курии положительно влиял на уровень расходов земств на образование и здравоохранение [Naftziger 2011, pp. 415-431].

Таблица 3. Темпы роста объема финансирования здравоохранения в реальном выражении

\begin{tabular}{|c|c|c|c|c|c|c|}
\hline \multirow{2}{*}{ Территория (губерния) } & \multicolumn{2}{|c|}{ 1870-e - 1913 г. } & \multicolumn{2}{|c|}{$\begin{array}{c}\text { 1870-e - середина } \\
\text { 1880-х гг. }\end{array}$} & \multicolumn{2}{|c|}{$\begin{array}{c}\text { Середина } \\
\text { 1880-x-1913 г. }\end{array}$} \\
\hline & $\begin{array}{l}\text { В целом за } \\
\text { период, раз }\end{array}$ & $\begin{array}{c}\text { В среднем } \\
\text { за год, \% }\end{array}$ & $\begin{array}{l}\text { В целом за } \\
\text { период, раз }\end{array}$ & $\begin{array}{c}\text { В среднем } \\
\text { за год, \% }\end{array}$ & $\begin{array}{l}\text { В целом за } \\
\text { период, раз }\end{array}$ & $\begin{array}{c}\text { В среднем } \\
\text { за год, } \%\end{array}$ \\
\hline Российская империя & н/д & н/д & $\mathrm{H} /$ д & $\mathrm{H} /$ д & 4,85 & 5,80 \\
\hline Архангельская & н/д & н/д & н/д & н/д & н/д & $8,44^{\mathrm{a}}$ \\
\hline Вологодская & $8,52^{\mathrm{b}}$ & 6,31 & н/д & $9,52^{\mathrm{c}}$ & 4,51 & 5,52 \\
\hline Вятская & н/д & $\mathrm{H} /$ д & н/д & $3,33^{d}$ & 4,12 & 5,19 \\
\hline Екатеринославская & $\mathrm{H} /$ д & $\mathrm{H} /$ д & $\mathrm{H} /$ д & $6,22^{\mathrm{c}}$ & 2,09 & 2,66 \\
\hline Калужская & $2,47^{\mathrm{e}}$ & 2,70 & н/д & $0,26^{\mathrm{f}}$ & 2,43 & 3,23 \\
\hline Курская & 7,99 & 4,95 & 2,02 & 4,81 & 3,95 & 5,03 \\
\hline Новгородская & н/д & $3,33^{\mathrm{g}}$ & н/д & $3,61^{\mathrm{h}}$ & $2,43^{\mathrm{f}}$ & 3,22 \\
\hline Пензенская & н/д & $\mathrm{H} /$ д & н/д & н/д & 2,21 & 2,88 \\
\hline Пермская & $\mathrm{H} /$ д & $\mathrm{H} / д$ & н/д & 2,43 & 2,86 & 3,83 \\
\hline Псковская & $3,22^{\mathrm{i}}$ & 3,61 & $\mathrm{H} /$ д & $7,34^{\mathrm{j}}$ & $2,13^{\mathrm{k}}$ & 2,74 \\
\hline Рязанская & 2,60 & 2,24 & 3,40 & 8,50 & 0,76 & $-0,96$ \\
\hline Саратовская & 4,67 & 3,65 & 1,32 & 1,89 & 3,53 & 4,61 \\
\hline Смоленская & 13,72 & 6,13 & 4,27 & 10,17 & 3,45 & 4,52 \\
\hline Тамбовская & н/д & н/д & 3,42 & 8,53 & н/д & $3,07^{1}$ \\
\hline Ярославская & $\mathrm{H} /$ д & $\mathrm{H} / д$ & $\mathrm{H} / д$ & 9,67 & 2,20 & 2,86 \\
\hline
\end{tabular}

Paccчuтано по: [Kaser 1974, pp. 248-249; Грегори 2003, с. 238, 240; Didenko et al. 2013] - по Российской империи; данным губернаторских годовых отчетов [Обзор 1870-1916]; дефлировано аналогично таблице 1.

Примечания: a $1895-1912$; b $1878-1913$; c $1878-1885$; d $1880-1885$; ${ }^{\mathrm{e}} 1879-1913$; ${ }^{\mathrm{f}} 1879-1885$; g $1874-1913$; ${ }^{\text {h }} 1874-1885 ;{ }^{i} 1877-1910 ;{ }^{j} 1877-1885 ;{ }^{k} 1882-1910 ;{ }^{1} 1885-1900$ 
Таблица 4. Место (ранг) регионов по объему финансирования здравоохранения в реальном выражении

\begin{tabular}{|c|c|c|c|c|c|}
\hline \multirow{2}{*}{ Губерния } & \multicolumn{2}{|c|}{ Объемы, руб. 1913 г. } & \multicolumn{2}{|c|}{ Ранги } & \multirow{2}{*}{$\begin{array}{c}\text { Изменение } \\
\text { ранга }\end{array}$} \\
\hline & 1880 г. & 1910 г. & 1880 г. & 1910 г. & \\
\hline Вятская & 514082 & 2331121 & 4 & 4 & 0 \\
\hline Екатеринославская & 751634 & 2163882 & 2 & 5 & -3 \\
\hline Новгородская & 293149 & 884281 & 9 & 11 & -2 \\
\hline Смоленская & 258860 & 1040665 & 10 & 8 & 2 \\
\hline Ярославская & 185869 & 1475719 & 12 & 6 & 6 \\
\hline Вологодская & 233191 & 1426336 & 7 & 4 & 3 \\
\hline Калужская & 350218 & 1030654 & 4 & 5 & -1 \\
\hline Курская & 411898 & 2754962 & 3 & 2 & 1 \\
\hline Пермская & 1296783 & 3735895 & 1 & 1 & 0 \\
\hline Псковская & 319326 & 893629 & 6 & 6 & 0 \\
\hline Рязанская & 323153 & 493097 & 5 & 7 & -2 \\
\hline Саратовская & 677268 & 2726526 & 2 & 3 & -1 \\
\hline
\end{tabular}

Рассчитано по: [Обзор 1871-1915] (данные губернаторских годовых отчетов); дефлировано аналогично таблище 1.

Таким образом, описанная нами динамика во многом отражала потенциал регионов, и вполне закономерно, что в условиях начавшейся индустриализации это скорее вело к их дивергенции. Аналогичный процесс происходил во второй половине XIX в. в Пруссии, добившейся наивысшего среди европейских стран уровня охвата начальным образованием в условиях децентрализованной системы его финансирования [Lindert 2004, vol. 1, pp. 87-89, 115-121] и служившей в этой сфере источником многих институциональных заимствований для России [Рождественский 1902, с. 491-493, 537-540].

\section{Насколько равномерно шло накопление человеческого капитала в период современного экономического роста?}

В предыдущей главе мы анализировали проблему пространственной неравномерности накопления человеческого капитала в категориях опережающей и отстающей динамики регионов относительно друг друга и страны в целом. В настоящем разделе мы переходим непосредственно к измерению уровня дифференциации и его изменений с течением времени. Мы попытаемся ответить на вопрос: реализовались ли в России рассматриваемого периода предсказания моделей С. Кузнеца и Дж. Барро - Х. Сала-и-Мартина? Для начала рассмотрим динамику натуральных показателей. Если мы сравним уровни охвата образованием в 1880 и в 1913 г. (рисунок 1), то увидим, что в долгосрочной ретроспективе более быстрое 
увеличение охвата населения образованием имело место именно в тех регионах, где в большей степени требовалось восполнить его недостаток. Коэффициент детерминации около 0,7 свидетельствует о статистически сильной $\beta$-конвергенции регионов по уровню охвата образованием. В результате коэффициент вариации между шестью губерниями по общему охвату населения разными формами образования понизился с 14,2 до 10,0\% (б-конвергенция). В то же время по объему финансирования одного учащегося шел процесс, противоположный $\beta$-конвергенции, что продемонстрировано на рисунке 2. В результате коэффициент вариации между шестью губерниями по удельному финансированию образования за период с 1880 по 1910 г. поднялся с 30,4 до 42,3\% (отрицательная $\sigma$-конвергенция).

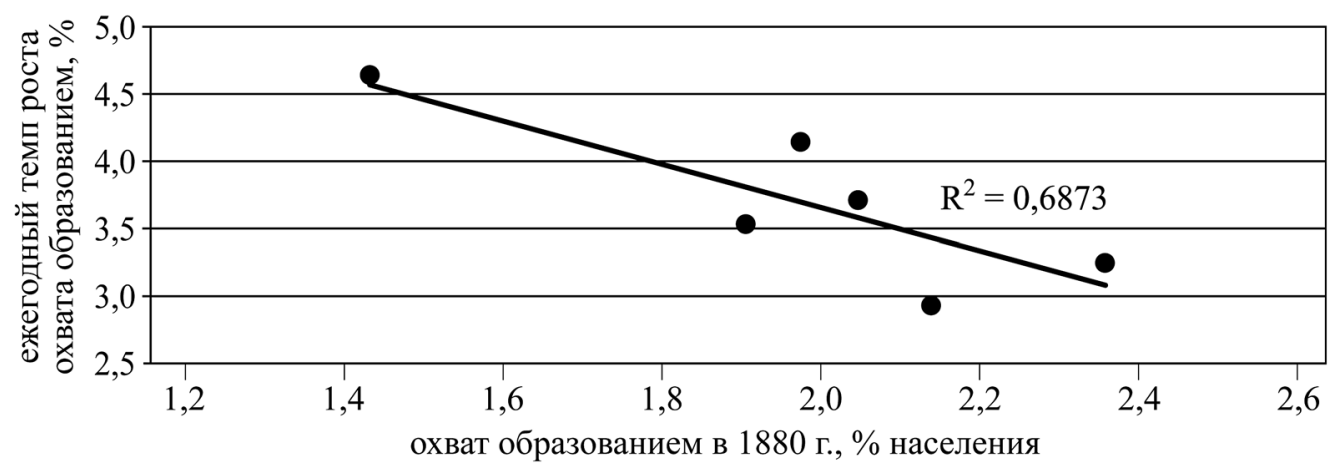

Рисунок 1. Начальные уровни охвата населения образованием и их последующее увеличение, $1880-1913$ гг.

Рассчитано по: [Обзор 1870-1916] (данные губернаторских годовых отчетов).

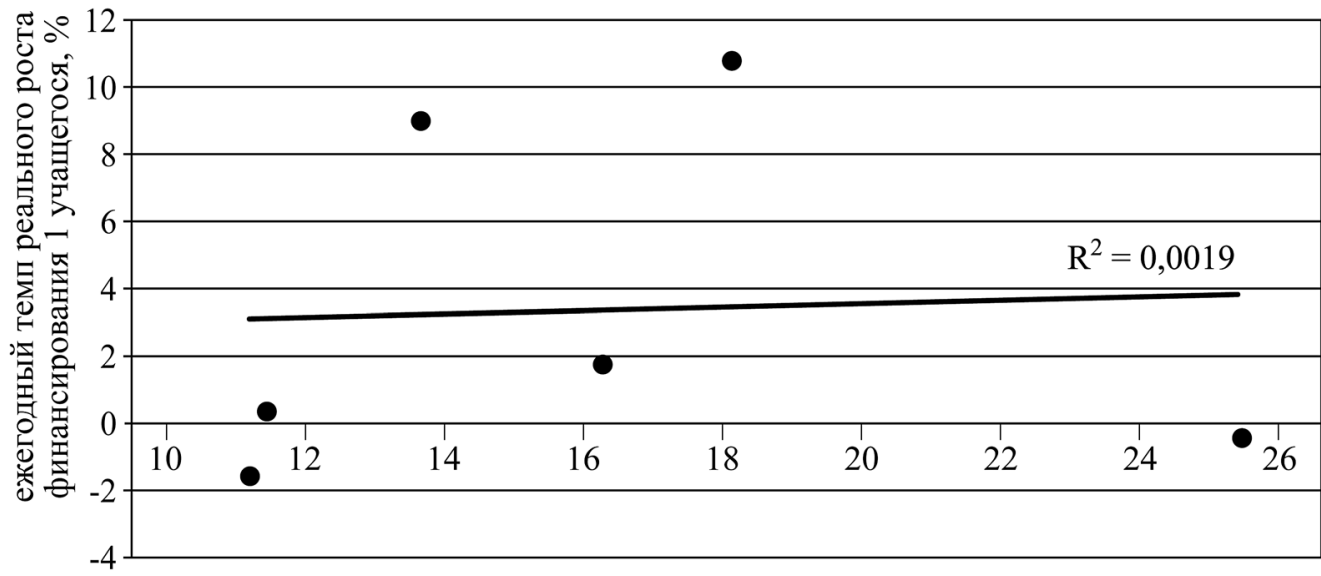

объем финансирования 1 учащегося в 1880 г., руб. 1913 г.

Рисунок 2. Начальные уровни объема финансирования 1 учащегося и их последующее реальное увеличение, 1880-1910 гг.

Рассчитано по: [Обзор 1870-1916] (данные губернаторских годовых отчетов). 
Как видно из рисунка 3 , долгосрочные процессы $\beta$-конвергенции не наблюдались в сфере здравоохранения, где коэффициент вариации между шестью губерниями по обеспеченности населения медицинским персоналом за 30 лет поднялся с 24,4 до $32,8 \%$.

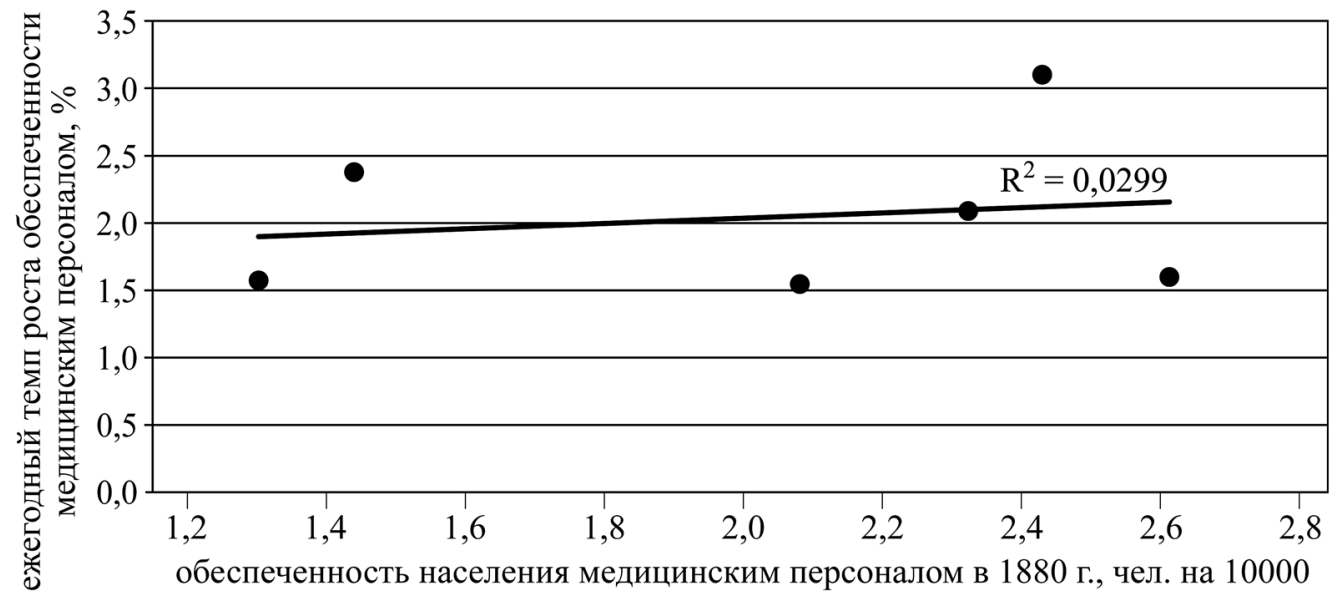

Рисунок 3. Начальные уровни обеспеченности населения медицинским персоналом и их последующее увеличение, 1880-1910 гг.

Рассчитано по: [Обзор 1870-1916] (данные губернаторских годовых отчетов).

Для совокупной оценки пространственной дифференциации по объему финансирования за определенный год мы также использовали коэффициент вариации. Как видно на рисунке 4, наша гипотеза о преобладании тенденций к возрастанию дифференциации при переходе к современному экономическому росту подтвердилась лишь отчасти: межрегиональная дифференциация по финансированию образования увеличивалась только на протяжении 1870-х гг. (ранний период становления земств), но за последующие более чем 30 лет вернулась ближе к прежнему уровню. Межрегиональная дифференциация по финансированию здравоохранения показала сильные колебания, но к концу рассматриваемого периода ее уровень был несколько выше, чем в конце 1870-х гг. Примечательно, что период снижения дифференциации приходился на 1880-е - середину 1890-х гг., период активной государственной политики стимулирования индустриализации и расширения расходов центрального правительства. В дальнейшем уровень пространственной дифференциации финансирования образования стабилизировался, а в сфере здравоохранения (где средства центрального правительства составляли значительно меньшую долю) стал расти.

В Российской империи финансирование образования в значительной степени осуществлялось централизованно из средств центрального правительства. Его ориентир социальной политики мог заключаться в корректировке возникавших территориальных диспропорций в распределении этого важного компонента нематериального благосостояния и одновременно фактора производства. 
Здравоохранение, где в целом в период 1870-х - начала 1910-х гг. преобладала тенденция к повышению пространственной дифференциации, по большей части финансировалось земствами, коммерческими и некоммерческими организациями, домохозяйствами, т. е. за счет местных источников.

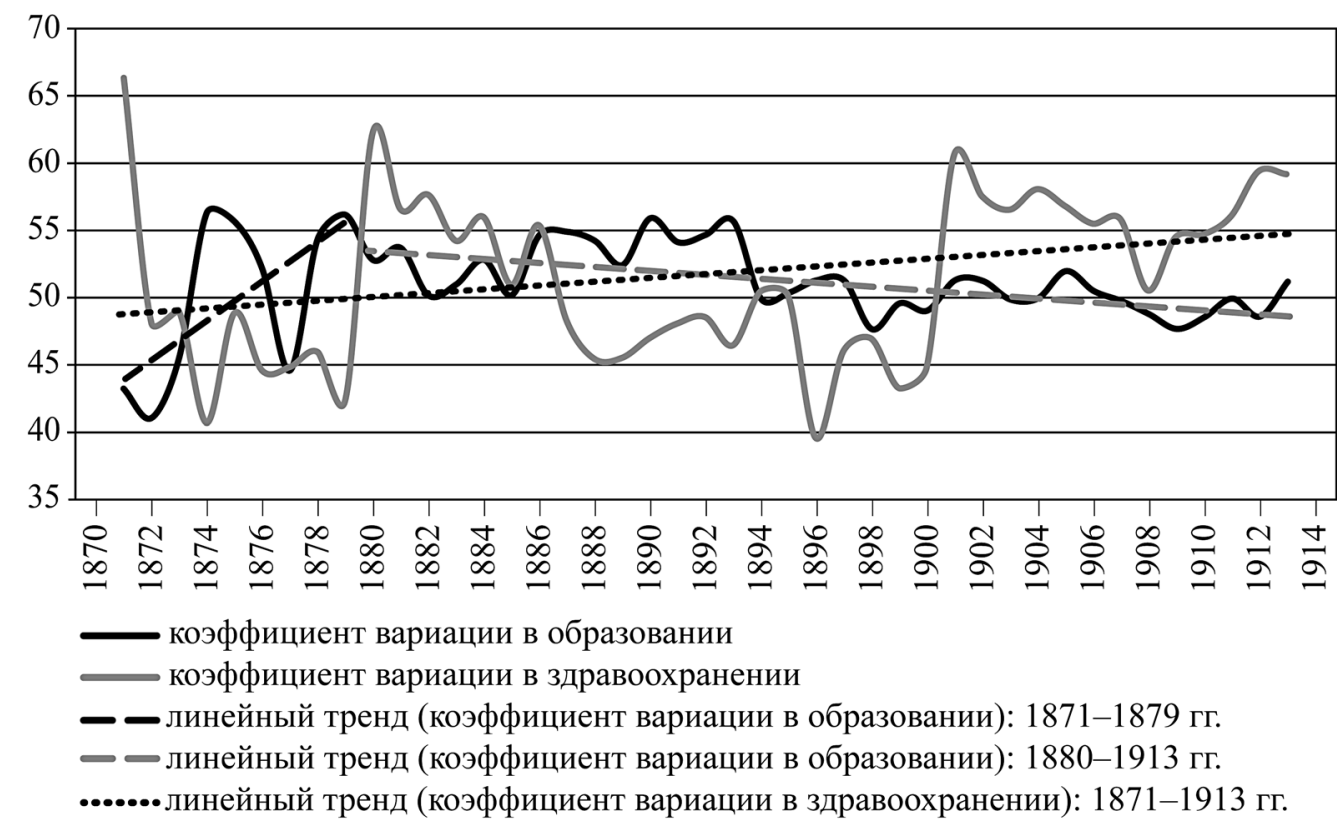

Рисунок 4. Динамика дифференциации финансирования образования и здравоохранения по выборке губерний Европейской России

Рассчитано по: [Обзор 1870-1916] (данные губернаторских годовых отчетов).

В данной ситуации возникает вопрос о согласованности уровней налоговых поступлений и структуры расходов земств. В отношении обложения предпринимательской деятельности центральным правительством устанавливались ограничения [Абрамов 1996, с. 20-21], в связи с чем основное место занимало обложение недвижимого имущества. Из приводимых С. Нафцигером данных [Naftziger 2011, p. 403] следует, что коэффициент вариации уровня налогообложения земли уездными земствами за 25 лет поднялся незначительно: с $43 \%$ в 1877 г. до 47\% в 1903 г. С одной стороны, земства разных регионов, укрепившиеся к концу XIX в. в качестве института местного самоуправления, могли обмениваться информацией (в т. ч. публиковавшейся Центральным статистическим комитетом МВД (напр., [Статистический временник Российской империи 1886]) и фактически проводить в той или иной степени скоординированную политику в отношении уровня финансирования образования и здравоохранения, которые нормативно не относились к обязательным расходам. В то же время в условиях отсутствия до 1905 г. легальных общероссийских межземских институтов согласование уровней налоговых поступлений и структуры расходов земств могло осуществляться 
исключительно неформально (в частности, на легальных съездах профессиональных организаций учителей, врачей, частных совещаниях глав земств, нелегальных земских съездах $)^{10}$. Но даже с появлением легальных общеземских съездов и организаций такие согласования вряд ли выходили за рамки обмена информацией. Во всяком случае, мы не располагаем сведениями о решениях, которые содержали бы соответствующие количественные рекомендации.

Положительная связь дифференциации финансирования образования и здравоохранения с долей средств центрального правительства в расходах на эти цели ${ }^{11}$ демонстрируют тенденции на рисунках 5 и 6 , хотя такая связь проявилась как недостаточно тесная, о чем свидетельствует низкий коэффициент детерминации.

Первоначальные элементы пространственной стратегии формирования человеческого капитала могли существовать на уровне Министерства финансов, Министерства народного просвещения (МНП) и Священного Синода. Расходы других ведомств, которые, исходя из данных в [Грегори 2003, с. 142-143, 146; Johnson 1950, p. 292], в 1913 г. составляли около 20\% расходов центрального правительства на образование, были подчинены скорее нуждам их основной деятельности, концентрировались в столичных городах и крупных административных, военных, промышленных и транспортных центрах.

В отношении финансово-бюджетной политики Министерство финансов, с одной стороны, исходило из необходимости учета местных особенностей недавно присоединенных частей империи, с другой, учитывало долгосрочную необходимость их интеграции. Так, национальные окраины имели отдельные бюджетные системы, функционировавшие по разным правилам, как и особые механизмы взаимодействия с бюджетом империи [Правилова 2006]. Однако переход на единую бюджетную систему Царства Польского в 1866 г. (после более полувекового самостоятельного функционирования) может являться примером реализации имперской интеграционной политики.

Существенные аспекты политики пространственного конструирования в сфере образования на раннем этапе выражались в требованиях наличия в каждом губернском городе 4-классного главного народного училища (введено в 1786 г.), а затем и гимназии (введено в 1803 г.); в каждом уездном городе - 2-классного малого народного училища (введено в 1786 г.), затем 3 -классного уездного училища (введено в 1803 г.); а также в разделении территории Российской империи на учебные округа с несколькими губерниями (согласно указу от 24.01.1803) [Рождественский 1902, с. 52-55]. Соответствующие нормативные документы утверждались на уровне высшей государственной власти.

Другим направлением пространственной политики выступало определение круга изучаемых дисциплин, нормативов преподавательского состава в увязке с нормами его финансирования (в одних случаях - единых для всей страны, в других - дифференцированных в зависимости от региона). Ее ключевым моментом стало установление общероссийских нормативов финансирования уездных училищ, гимназий и университетов, утвержденных Министерством народного

\footnotetext{
10 Упоминания о таком координировании, в т. ч. вопросов финансирования образования, приводятся в [Леонтович 1995, с. 341-343].

11 По 15 губерниям нашей выборки (из 50 губерний Европейской России), данные по которым обладают достаточной полнотой для реконструкции институциональной структуры расходов.
} 


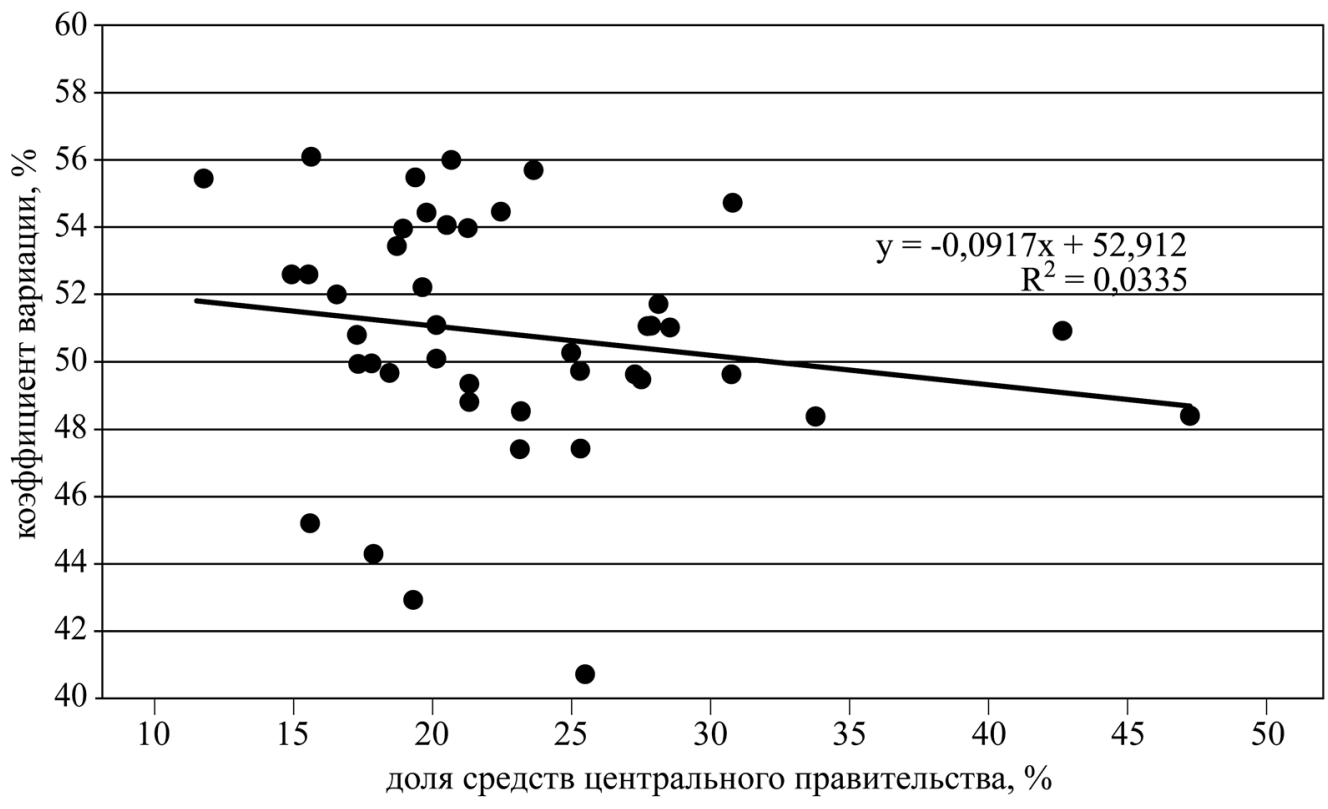

Рисунок 5. Динамика пространственной дифференциации финансирования образования в зависимости от доли средств центрального правительства по выборке губерний Европейской России

Рассчитано по: [Обзор 1870-1916] (данные губернаторских годовых отчетов).

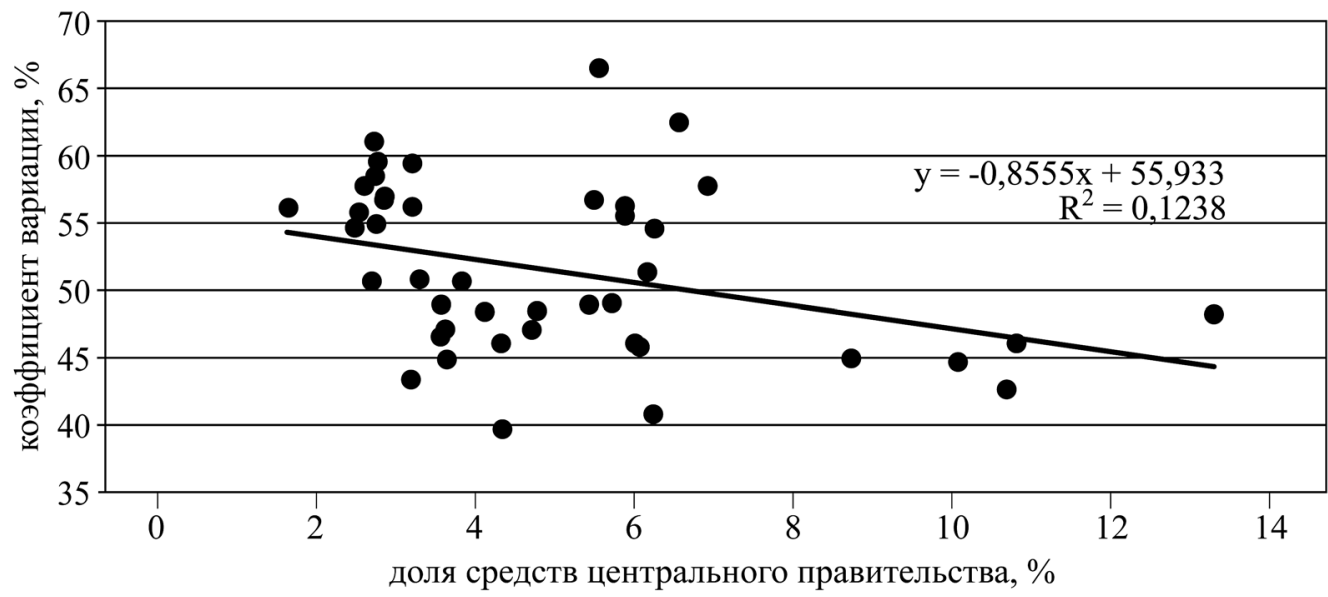

Рисунок 6. Динамика пространственной дифференциации финансирования здравоохранения в зависимости от доли средств центрального правительства по выборке губерний Европейской России

Рассчитано по: [Обзор 1870-1916] (данные губернаторских годовых отчетов). 
просвещения в 1803 г. и допускавших некоторые исключения [Сборник постановлений по Министерству народного просвещения 1875, с. 30-37]. Соответственно, реализация пространственной политики могла осуществляться главным образом через регулирование численности массовых учебных заведений и преподавателей. Таким образом, даже если пространственная политика не была зафиксирована в отдельном нормативном документе, а была составной частью общей образовательной политики, наличие данных требований в начале рассматриваемого периода свидетельствует о понимании центральными органами государственной власти Российской империи необходимости преодоления сильных межрегиональных различий в долгосрочной перспективе, хотя и не всегда отрефлексированного, при этом приоритеты в отношении централизации и децентрализации могли изменяться во времени.

К концу XIX в. в основных странах Западной Европы финансирование образования из общественных источников стало вполне сложившейся тенденцией [Lindert 2004, vol. 2, p. 153], однако преобладавшей практикой оставалось участие региональных и местных бюджетов [Lindert 2004, vol. 1, pp. 110-127]; наибольшее участие центрального правительства было характерно для Франции [Lindert 2004, vol. 1, p. 111]. Россия, таким образом, имела возможность комбинировать различные модели: от централизации в первой половине XIX в. к децентрализации в середине 1860 -х - середине 1880 -х гг. с новым этапом централизации с середины 1890-х гг. Если в 1830-х гг. Министерство народного просвещения не проявляло инициативы в открытии приходских и уездных училищ и предпочитало «идти навстречу желаниям самих местных обществ» [Рождественский 1902, с. 282], то с 1860-х гг. оно стало занимать более активную позицию. В 1860-е гг. была проведена унификация управления образованием в крупных регионах (учебных округах) через институты попечителей и инспекторов МНП [Рождественский 1902, с. 491-493]. Помимо этого, в 1873 г. МНП выступило с инициативой (не полностью одобренной) ввести в неземских губерниях подушевой норматив обеспеченности населения начальным образованием (одно начальное училище на 1000 чел. мужского населения) и подготовки соответствующих кадров учителей [Рождественский 1902, с. 553]. Признав уже в середине 1870-х гг. необходимость перехода к всеобщему начальному обучению, высшие должностные чины МНП осознали, что оно должно вводиться с учетом разнообразия экономических и климатических условий по мере поступления ходатайств земств, городских и сельских обществ [Рождественский 1902, с. 565].

Еще более четко приоритеты пространственной политики были сформулированы в конце 1890-х гг: задача МНП понималась в финансировании тех территорий с низким охватом населения начальным образованием [Рождественский 1902, с. 726]. Данный подход к его финансированию был закреплен в законе от 3 мая 1908 г. № 30328 [Полное собрание законов Российской империи 1911, с. 228-229], в котором предусматривалось выделение дополнительных средств МНП с учетом активизировавшегося обсуждения вопроса о введении всеобщего начального образования. В 1911 г. Государственная Дума проголосовала за принятие соответствующего законопроекта, который, однако, не получил одобрения Государственного совета [Абрамов 1996, с. 117].

Значительно меньшее внимание со стороны центральных органов государственной власти уделялось здравоохранению (в гражданской части), которое 
на протяжении рассматриваемого периода регулировалось не отдельным ведомством, а профильным подразделением в составе Министерства внутренних дел. В то же время в сфере здравоохранения наблюдались не столько институциональные заимствования из более развитых стран, сколько распространившиеся в практике работы земств инновационные институты (бесплатное участковое обслуживание населения, сочетание лечебной и санитарно-профилактической деятельности) [Абрамов 1996, с. 145-146].

\section{Заключение}

В конце XIX - начале XX в. Россия, как страна догоняющего типа модернизации, показала впечатляющие результаты в темпах накопления человеческого капитала, прежде всего в сфере образования; рост наблюдался как по натуральным, так и по стоимостным показателям. Однако процессы формирования человеческого капитала за периоды запуска и начала современного экономического роста протекали в российских регионах неравномерно.

Нами был рассмотрен важный вопрос о динамике пространственного неравенства в Европейской России в сфере накопления человеческого капитала. Мы установили, что процессы образовательной модернизации разворачивались неравномерно, различие в значениях натуральных и удельных финансовых показателей было довольно значимым и могло показывать различную динамику. Вслед за повышением пространственная дифференциация снижалась наиболее заметно в сфере финансирования образования, где возрастало участие центрального правительства, и за счет этого умеренно понижалась роль местного самоуправления. Напротив, в сфере здравоохранения, в финансировании которого участие центрального правительства было значительно скромнее, скорее наблюдалась дивергенция регионов.

Таким образом, взаимодействие стимулов к дивергенции и конвергенции в рамках единого политического образования (Российской империи) имело различные результаты. Кроме того, установленные феномены и тенденции интерпретируются как новые свидетельства повышенной роли центрального правительства в накоплении человеческого капитала в соответствии с концепцией [Гершенкрон 2015] о типологических особенностях экономического развития в «отставших» странах, осуществляющих догоняющую модернизацию.

По мере расширения выборки губерний мы имеем возможность исследовать степень и тренды дифференциации между разными регионами, при том что наличие общего для них тренда к расширению образовательного пространства и системы здравоохранения, способствовавших демографическому переходу в ходе процессов трансформации традиционного аграрного общества в современное индустриальное, вряд ли подлежит сомнению. При этом отмечен противоречивый характер тенденций в основных сферах формирования человеческого капитала. Сравнение с аналогичными процессами, происходившими в других странах на сопоставимом уровне развития, могло бы дать дополнительные аргументы в освещении данного вопроса. Тем не менее проведенный анализ подкрепляет трактовку имперской модернизации как проекта, имевшего значительную вероятность стать успешным, чем обреченного на неудачу. 


\section{Литература}

Абрамов В.Ф. (1996) Российское земство: экономика, финансы, культура. М.: Ника.

Барро Р.Дж., Сала-и-Мартин Х. (2010 [2004]) Экономический рост. М.: БИНОМ.

Бражникова А.С. (2013) Губернаторский отчет: изучение источника в отечественной историографии // Вестник Челябинского государственного университета. История. Вып. 55. № 12(303). С. 83-89.

Бычков Н.М. (1894) Финансы крупнейших русских городов. Москва: Городская типография. Волков Е.3. (1930) Динамика народонаселения СССР за 80 лет. М.: Госиздат.

Гершенкрон А. (2015 [1962, 1968]) Экономическая отсталость в исторической перспективе. М.: Дело.

Грегори П. (2003 [1982, 1994]) Экономический рост Российской империи (конец XIX в. начало ХХ в.): Новые подсчеты и оценки. М.: РОССПЭН.

Диденко Д.В. (2015) Интеллектуалоемкая экономика: Человеческий капитал в российском и мировом социально-экономическом развитии. СПб.: Алетейя.

Дятлова Н.П. (1964) Отчеты губернаторов как исторический источник // Проблемы архивоведения и источниковедения. Л.: Наука. С. 227-246.

Кендрик Дж. (1978 [1976]) Совокупный капитал США и его формирование. М.: Прогресс.

Кесслер Х., Маркевич А. (2014-2019) Электронный архив Российской исторической статистики, XVIII-XXI вв. // http://ristat.org/

Кискидосова Т.А. (2016) Губернаторские годовые отчеты как источник по изучению городского населения Восточной Сибири в 1850-1880-е гг. // Вестник Томского государственного университета. № 412. С. 50-53.

Леонтович В.В. (1995 [1957]) История либерализма в России: 1762-1914. М.: Русский путь - Полиграфресурсы.

Миронов Б.Н. (1994) Экономический рост и образование в России и СССР в XIX-XX веках // Отечественная история. № 4-5. С. 111-125.

Миронов Б.Н. (2010) Благосостояние населения и революции в имперской России: XVIII - начало XX в. М.: Новый хронограф.

Миронов Б.Н. (2014-2015) Российская империя: от традиции к модерну. В 3-х тт. СПб.: Дмитрий Буланин.

Обзор Архангельской губернии (1871-1916) // Приложение к всеподданнейшему отчету. Архангельск.

Обзор Вологодской губернии (1871-1915) // Приложение к всеподданнейшему отчету. Вологда.

Обзор Вятской губернии (1871-1916) // Приложение к всеподданнейшему отчету. Вятка.

Обзор Екатеринославской губернии (1890-1913) // Приложение к всеподданнейшему отчету. Екатеринослав.

Обзор Калужской губернии (1871-1915) // Приложение к всеподданнейшему отчету. Калуга.

Обзор Курской губернии (1870-1916) // Приложение к всеподданнейшему отчету. Курск.

Обзор Новгородской губернии (1871-1916) // Приложение к всеподданнейшему отчету. Новгород.

Обзор Пензенской губернии (1880-1915) // Приложение к всеподданнейшему отчету. Пенза.

Обзор Пермской губернии (1870-1916) // Приложение к всеподданнейшему отчету. Пермь. Обзор Псковской губернии (1871-1911) // Приложение к всеподданнейшему отчету. Псков. Обзор Рязанской губернии (1871-1915) // Приложение к всеподданнейшему отчету. Рязань. Обзор Саратовской губернии (1871-1915) // Приложение к всеподданнейшему отчету. Саратов.

Обзор Смоленской губернии (1871-1915) // Приложение к всеподданнейшему отчету. Смоленск.

Обзор Тамбовской губернии (1871-1911) // Приложение к всеподданнейшему отчету. Тамбов. 
Обзор Ярославской губернии (1872-1915) // Приложение к всеподданнейшему отчету. Ярославль.

Полное собрание законов Российской Империи (1911). Собрание 3-е. T. XXVIII. 1908. Отделение 1. № 30328. СПб.: Гос. тип.

Правилова Е.А. (2006) Финансы империи: Деньги и власть в политике России на национальных окраинах, 1801-1917. М.: Новое издательство.

Проект «Динамика экономического и социального развития России в XIX - начале XX вв.» (2012) // http://www.hist.msu.ru/Dynamics/index.html

Рашин А.Г. (1956) Население России за 100 лет (1811-1913 гг.): Статистические очерки. М.: Государственное статистическое издательство.

Рождественский С.В. (сост.) (1902) Исторический обзор деятельности Министерства народного просвещения: 1802-1902. СПб.: М-во нар. прос.

Ростоу В.В. (1961) Стадии экономического роста. Нью-Йорк: Издательство Фредерик А. Прегер.

Сборник постановлений по Министерству народного просвещения (1875). 2-е изд. Т. 1: Царствование императора Александра I. 1802-1825. СПб.: Тип. В.С. Балашева.

Статистический временник Российской империи (1886). Сер. III. Вып. 16 // Доходы и расходы губернских и уездных земств за 1883 год. СПб.: Центральный статистический комитет Министерства внутренних дел.

Струмилин С.Г. (1954) История черной металлургии в СССР. Т. 1. М.: Академия наук СССР.

Суворов А.В., Суворов Н.В., Гребенников В.Г., Иванов В.Н., Балашова Е.Е., Трещина С.В., Бондаренко Н.В., Красильникова М.Д., Болдов О.Н. (2016) Человеческий капитал как фактор социально-экономического развития России. СПб.: Нестор-История.

Шараго В.И. (ред.) (1914) Статистический ежегодник на 1914 г. СПб.: Совет съездов представителей промышленности и торговли.

Ярцев А.А. (2015) Губернаторские отчеты как источник по истории самоуправления в Российской империи // Калининградские архивы. № 12. С. 16-25.

Яснопольский Н.П. (1897) Приложения к исследованию о географическом распределении государственных расходов в России: Статистические таблицы, картограммы и диаграммы. Ч. 2. Киев: Тип. Киевского Императорского университета.

Baten J., Hippe R. (2018) Geography, Land Inequality and Regional Numeracy in Europe in Historical Perspective // Journal of Economic Growth, vol. 23, no 1, pp. 79-109. DOI: $10.1007 / \mathrm{s} 10887-017-9151-1$

Baten J., Szołtysek M., Campestrini M. (2017) “Girl Power” in Eastern Europe? The Human Capital Development of Central-Eastern and Eastern Europe in the Seventeenth to Nineteenth Centuries and Its Determinants // European Review of Economic History, vol. 21, no 1, pp. 29-63.

Beugelsdijk S., Klasing M.J., Milionis P. (2018) Regional Economic Development in Europe: The Role of Total Factor Productivity // Regional Studies, vol. 52, no 4, pp. 461-476. DOI: $10.1080 / 00343404.2017 .1334118$

Breinlich H., Ottaviano G.I.P., Temple J.R.W. (2014) Regional Growth and Regional Decline // Handbook of Economic Growth, vol. 2 (eds. Aghion P., Durlauf S.N.), Amsterdam: Elsevier B.V., pp. 683-779.

Cheremukhin A., Golosov M., Guriev S., Tsyvinski A. (2017) The Industrialization and Economic Development of Russia through the Lens of a Neoclassical Growth Model // Review of Economic Studies, vol. 84, no 2, pp. 613-649. DOI: 10.1093/restud/rdw026

Crayen D., Baten J. (2010) New Evidence and New Methods to Measure Human Capital Inequality before and during the Industrial Revolution: France and the US in the Seventeenth to Nineteenth Centuries // The Economic History Review, vol. 6, no 2, pp. 452-478. DOI: $10.1111 /$ j.1468-0289.2009.00499.x

Didenko D.V. (2012) Income Inequality and Systemic Transformations: Long-term Trends of Human Capital Private Returns // Journal of Comparative Economic Studies, vol. 7, pp. 53-87.

Didenko D.V. (2019) The Role of Institutional Sectors of Regional Economy in Human Capital Formation in European Russia (late 19th - early 20th Centuries) // Perm University Herald. Economy, vol. 14, no 4, pp. 518-536. DOI: 10.17072/1994-9960-2019-4-518-536 
Didenko D., Földvári P., Van Leeuwen B. (2013) The Spread of Human Capital in the Former Soviet Union Area in a Comparative Perspective: Exploring a New Dataset // Journal of Eurasian Studies, vol. 4, no 2, pp. 123-135 // https://www.sciencedirect.com/science/article/pii/S1879366513000122

Diebolt C., Hippe R. (2017) Regional Human Capital Inequality in Europe in the Long-Run, 1850-2010 // Région et Développement, no 45, pp. 5-30.

Diebolt C., Hippe R. (2018) Remoteness Equals Backwardness? Human Capital and Market Access in the European Regions: Insights from the Long Run // Education Economics, vol. 26, no 3, pp. 285-304.

Easterly W., Fischer S. (1995) The Soviet Economic Decline: Historical and Republican Data // World Bank Economic Review, vol. 9, no 3, pp. 341-371 // https://www.nber.org/papers/w4735

Feenstra R.C., Inklaar R., Timmer M.P. (2015) The Next Generation of the Penn World Table // American Economic Review, vol. 105, no 10, pp. 3150-3182 // https://www.rug.nl/ggdc/docs/the_next_generation_of the penn_world table.pdf

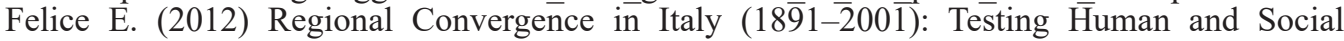
Capital // Cliometrica, vol. 6, no 3, pp. 267-306.

Johnson W.H.E. (1950) Russia's Educational Heritage, Pittsburg: Carnegie Press.

Kaser M. (1974) Education in Tsarist and Soviet Development // Essays in Honour of E.H. Carr (ed. Abramsky C.), London: Macmillan, pp. 229-254.

Kuznets S. (1955) Economic Growth and Income Inequality // American Economic Review, vol. 45, no 1 , pp. 1-28.

Kuznets S. (1966) Modern Economic Growth: Rate, Structure, and Spread, New Haven, London: Yale University Press.

Lau L.J., Jamison D.T., Liu S.-C., Rivkin S. (1993) Education and Economic Growth: Some Cross-Sectional Evidence from Brazil // Journal of Development Economics, vol. 41, no 1, pp. $45-70$.

Lindert P.H. (2004) Growing Public: Social Spending and Economic Growth since the Eighteenth Century. 2 volumes, Cambridge: Cambridge University Press.

Markevich A. (2018) A Regional Perspective on the Economic Development of the Late Russian Empire. DOI: 10.2139/ssrn.2555273

Naftziger S. (2011) Did Ivan's Vote Matter? The Political Economy of Local Democracy in Tsarist Russia // European Review of Economic History, vol. 15, no 3, pp. 393-441.

Tabellini G. (2010) Culture and Institutions: Economic Development in the Regions of Europe // Journal of the European Economic Association, vol. 8, no 4, pp. 677-716. DOI: $10.1111 / \mathrm{j} .1542-4774.2010 . t b 00537 . \mathrm{x}$

Turner C., Tamura R., Mulholland S.E., Baier S. (2007) Education and Income of the States of the United States: 1840-2000 // Journal of Economic Growth, vol. 12, no 2, pp. 101-158.

Turner C., Tamura, R., Mulholland S., Baier S. (2013) How Important Are Human Capital, Physical Capital and Total Factor Productivity for Determining State Economic Growth in the United States, 1840-2000? // Journal of Economic Growth, Springer, vol. 18, no 4, pp. 319-371.

Van Leeuwen B., Didenko D., Földvári P. (2015) Inspiration versus Perspiration in Economic Development of the Former Soviet Union and China (ca. 1920-2010) // Economics of Transition, vol. 23, no 1, pp. 213-246.

Van Leeuwen B., Van Leeuwen-Li J., Foldvari P. (2017) Human Capital in Republican and New China: Regional and Long-term Trends // Economic History of Developing Regions, vol. 32, no 1, pp. 1-36. 


\title{
Spatial Inequality and Human Capital Formation in the Transition of European Russia to the 'Modern' Type of Economic Growth (Late $19^{\text {th }}$ to Early 20 $^{\text {th }}$ Centuries)
}

\author{
D. DIDENKO*
}

\begin{abstract}
*Dmitry Didenko - DSc in Economics, PhD in History, Leading Researcher, Professor, Russian Presidential Academy of National Economy and Public Administration. Address: 82, Vernadskogo Av., Moscow, 119571, Russian Federation. E-mail: didenko-dv@ranepa.ru

Citation: Didenko D. (2021) Spatial Inequality and Human Capital Formation in the Transition of European Russia to the 'Modern' Type of Economic Growth (Late $19^{\text {th }}$ to Early $20^{\text {th }}$ Centuries). Mir Rossii, vol. 30, no 3, pp. 100-126 (in Russian). DOI: $10.17323 / 1811-038 X-2021-30-3-100-126$
\end{abstract}

\begin{abstract}
This article analyses spatial inequality in human capital formation in Russia during the transition to industrial development in the pre-revolutionary period. I employ annual governors' reports as the primary source of statistical data on financing education and health care. Using this data, I identify the patterns of human capital dynamics in various regions of Russia and discuss them against country-wide trends. My analysis reveals that Russia featured impressive rates of human capital formation, primarily through education, in the late $19^{\text {th }}$ century and in the early $20^{\text {th }}$ century. However, the processes of human capital formation in the Russian regions proceeded unevenly. In some cases, the regions changed their ranking in the financing of education and health care. I also apply the models of inequality dynamics by Kuznets (an inverted U-shaped curve at different stages of modern economic growth), Barro and Sala-i-Martin ( $\beta$-convergence and $\sigma$-convergence in unified political space). My findings suggest that in the period under study there was some convergence between the Russian regions in terms of educational enrollment and the amount of financing. Modest reverse processes were in force as regards funding per student and basic indicators of health care (access to medical personnel for the population, and financing). The study further reveals the factors which were driving the changing structure of the institutional sources of financing. Declining interregional differentiation in education was associated with the increasing share supplied by the central government and the declining share supplied by local governments (however, the central government's share remained relatively modest in health care). This new evidence supports Gerschenkron's idea of the elevated role of government in the socio-economic development of 'backward' countries undergoing catch-up modernization.
\end{abstract}

Keywords: regional development, convergence, divergence, annual governors' reports, public finance, education, health care 


\section{References}

Abramov V.F. (1996) Rossijskoe zemstvo: ekonomika, finansy, kul'tura [Russian Zemstvo: Economy, Finance, Culture], Moscow: Nika.

Barro R.J., Sala-i-Martin X. (2010 [2004]) Ekonomicheskij rost [Economic Growth], Moscow: Binom.

Baten J., Hippe R. (2018) Geography, Land Inequality and Regional Numeracy in Europe in Historical Perspective. Journal of Economic Growth, vol. 23, no 1, pp. 79-109. DOI: $10.1007 / \mathrm{s} 10887-017-9151-1$

Baten J., Szołtysek M., Campestrini M. (2017) “Girl Power” in Eastern Europe? The Human Capital Development of Central-Eastern and Eastern Europe in the Seventeenth to Nineteenth Centuries and Its Determinants. European Review of Economic History, vol. 21, no 1, pp. 29-63.

Beugelsdijk S., Klasing M.J., Milionis P. (2018) Regional Economic Development in Europe: The Role of Total Factor Productivity. Regional Studies, vol. 52, no 4, pp. 461-476. DOI: $10.1080 / 00343404.2017 .1334118$

Brazhnikova A.S. (2013) Gubernatorskij otchet: izuchenie istochnika v otechestvennoj istoriografii [Governor's Report: Studies of the Source in Domestic Historical Science]. Vestnik Cheliabinskogo gosudarstvennogo universiteta. Istoriya, vol. 55, no 12(303), pp. 83-89.

Breinlich H., Ottaviano G.I.P., Temple J.R.W. (2014) Regional Growth and Regional Decline. Handbook of Economic Growth, vol. 2, (eds. Aghion P., Durlauf S.N.), Amsterdam: Elsevier B.V. pp. 683-779.

Bychkov N.M. (1894) Finansy krupneishikh russkikh gorodov [Finances of the Largest Russian Cities], Moscow: Gorodskaya tipografiya.

Cheremukhin A., Golosov M., Guriev S., Tsyvinski A. (2017) The Industrialization and Economic Development of Russia through the Lens of a Neoclassical Growth Model. Review of Economic Studies, vol. 84, no 2, pp. 613-649. DOI: 10.1093/restud/rdw026

Crayen D., Baten J. (2010) New Evidence and New Methods to Measure Human Capital Inequality before and during the Industrial Revolution: France and the US in the Seventeenth to Nineteenth Centuries. The Economic History Review, vol. 6, no 2, pp. 452-478. DOI: $10.1111 / \mathrm{j} .1468-0289.2009 .00499 . x$

Dyatlova N.P. (1964) Otchety gubernatorov kak istoricheskij istochnik [Governors' Reports as a Historical Source]. Problemy arkhivovedeniya i istochnikovedeniya, Leningrad: Nauka, pp. 227-246.

Didenko D.V. (2012) Income Inequality and Systemic Transformations: Long-term Trends of Human Capital Private Returns. Journal of Comparative Economic Studies, vol. 7, pp. 53-87.

Didenko D.V. (2015) Intellektualoemkaya ekonomika: Chelovecheskij kapital v rossijskom $i$ mirovom sotsial'no-ekonomicheskom razvitii [Knowledge-intensive Economy: Human Capital in Russian and Global Socio-economic Development], Saint Petersburg: Aleteiya.

Didenko D.V. (2019) The Role of Institutional Sectors of Regional Economy in Human Capital Formation in European Russia (late 19th - early 20th Centuries). Perm University Herald. Economy, vol. 14, no 4, pp. 518-536. DOI: 10.17072/1994-9960-2019-4-518-536

Didenko D., Földvári P., Van Leeuwen B. (2013) The Spread of Human Capital in the Former Soviet Union Area in a Comparative Perspective: Exploring a New Dataset. Journal of Eurasian Studies, vol. 4, no 2, pp. 123-135. Available at: https:/www.sciencedirect.com/science/article/pii/S1879366513000122, accessed 21.04.2021.

Diebolt C., Hippe R. (2017) Regional Human Capital Inequality in Europe in the Long-Run, 1850-2010. Région et Développement, no 45, pp. 5-30.

Diebolt C., Hippe R. (2018) Remoteness Equals Backwardness? Human Capital and Market Access in the European Regions: Insights from the Long Run. Education Economics, vol. 26, no 3, pp. 285-304.

Easterly W., Fischer S. (1995) The Soviet Economic Decline: Historical and Republican Data. World Bank Economic Review, vol. 9, no 3, pp. 341-371. Available at: https://www.nber.org/papers/w4735, accessed 21.04.2021. 
Feenstra R.C., Inklaar R., Timmer M.P. (2015) The Next Generation of the Penn World Table. American Economic Review, vol. 105, no 10, pp. 3150-3182. Available at: https://www.rug.nl/ggdc/docs/the_next_generation_of_the_penn_world_table.pdf, accessed 21.04.2021.

Felice E. (2012) Regional Convergence in Italy (1891-2001): Testing Human and Social Capital. Cliometrica, vol. 6, no 3, pp. 267-306.

Gerschenkron A. (2015 [1962, 1968]) Ekonomicheskaya otstalost'v istoricheskoj perspektive [Economic Backwardness in Historical Perspective], Moscow: Delo.

Gregory P. (2003 [1982, 1994]) Ekonomicheskij rost Rossiiskoj imperii (konets XIX v. nachalo $X X$ v.): Novye podschety $i$ otsenki [Economic Growth of the Russian Empire (late 19th - early 20th centuries): New Calculations and Estimates], Moscow: ROSSPEN.

Johnson W.H.E. (1950) Russia's Educational Heritage, Pittsburg: Carnegie Press.

Kaser M. (1974) Education in Tsarist and Soviet Development. Essays in Honour of E.H. Carr (ed. Abramsky C.), London: Macmillan, pp. 229-254.

Kendrick J. (1978 [1976]) Sovokupnyj kapital SShA i ego formirovanie [The Formation and Stocks of Total Capital], Moscow: Progress.

Kessler G., Markevich A. (2014-2019) Elektronnyj arkhiv Rossiiskoj istoricheskoj statistiki, $X V I I I-X X I v v$. [Electronic Repository of Russian Historical Statistics, 18th - 21st Centuries]. Available at: http://ristat.org/, accessed 21.04.2019.

Kiskidosova T.A. (2016) Gubernatorskie godovye otchety kak istochnik po izucheniyu gorodskogo naseleniya Vostochnoj Sibiri v 1850-1880-e gg. [Governors' Annual Reports as a Source for Studies of the Eastern Siberian Urban Population in 1850-1880s]. Vestnik Tomskogo gosudarstvennogo universiteta, no 412, pp. 50-53.

Kuznets S. (1955) Economic Growth and Income Inequality. American Economic Review, vol. 45, no 1, pp. 1-28.

Kuznets S. (1966) Modern Economic Growth: Rate, Structure, and Spread, New Haven-London: Yale University Press.

Lau L.J., Jamison D.T., Liu S.-C., Rivkin S. (1993) Education and Economic Growth: Some CrossSectional Evidence from Brazil. Journal of Development Economics, vol. 41, no 1, pp. 45-70.

Leontovich V.V. (1995 [1957]) Istoriya liberalizma v Rossii: 1762-1914 [History of Liberalism in Russia: 1762-1914], Moscow: Russkij put' - Poligrafresursy.

Lindert P.H. (2004) Growing Public: Social Spending and Economic Growth since the Eighteenth Century. 2 volumes, Cambridge: Cambridge University Press.

Markevich A. (2018) A Regional Perspective on the Economic Development of the Late Russian Empire. DOI: $10.2139 /$ ssrn.2555273

Mironov B.N. (1994) Ekonomicheskij rost i obrazovanie v Rossii i SSSR v XIX-XX vekakh [Economic Growth and Education in Russia and the USSR in the 19th-20th Centuries]. Otechestvennaya istoriya, no 4-5, pp. 111-125.

Mironov B.N. (2010) Blagosostoyanie naseleniya i revoliutsii v imperskoj Rossii: XVIII-nachalo $X X v$. [Population Welfare and Revolutions in Imperial Russia: 18th - early 20th Centuries], Moscow: Novyj khronograf.

Mironov B.N. (2014-2015) Rossijskaya imperiya: ot traditsii $k$ modernu [Russian Empire: From Tradition to Modernity]. Vols. 1-3, Saint Petersburg: Dmitrij Bulanin.

Naftziger S. (2011) Did Ivan's Vote Matter? The Political Economy of Local Democracy in Tsarist Russia. European Review of Economic History, vol. 15, no 3, pp. 393-441.

Obzor Arkhangel'skoj gubernii [Review of Arkhangel'skaya Guberniya] (1871-1916). Prilozhenie $k$ Vsepoddannejshemu otchetu [Appendix to Most Humble Report], Arkhangelsk.

Obzor Ekaterinoslavskoj gubernii [Review of Ekaterinoslavskaya Guberniya] (1890-1913). Prilozhenie $k$ Vsepoddannejshemu otchetu [Appendix to Most Humble Report], Ekaterinoslav.

Obzor Kaluzhskoj gubernii [Review of Kaluzhskaya Guberniya] (1871-1915). Prilozhenie $k$ Vsepoddannejshemu otchetu [Appendix to Most Humble Report], Kaluga.

Obzor Kurskoj gubernii [Review of Kurskaya Guberniya] (1870-1916). Prilozhenie $k$ Vsepoddannejshemu otchetu [Appendix to Most Humble Report], Kursk.

Obzor Novgorodskoj gubernii [Review of Novgorodskaya Guberniya] (1871-1916). Prilozhenie $k$ Vsepoddannejshemu otchetu [Appendix to Most Humble Report], Novgorod. 
Obzor Penzenskoj gubernii [Review of Penzenskaya Guberniya] (1880-1915). Prilozhenie

$k$ Vsepoddannejshemu otchetu [Appendix to Most Humble Report], Penza.

Obzor Permskoj gubernii [Review of Permskaya Guberniya] (1870-1916). Prilozhenie k Vsepoddannejshemu otchetu [Appendix to Most Humble Report], Perm'.

Obzor Pskovskoj gubernii [Review of Pskovskaya Guberniya] (1871-1911). Prilozhenie $k$ Vsepoddannejshemu otchetu [Appendix to Most Humble Report], Pskov.

Obzor Ryazanskoj gubernii [Review of Riazanskaya Guberniya] (1871-1915). Prilozhenie k Vsepoddannejshemu otchetu [Appendix to Most Humble Report], Ryazan'.

Obzor Saratovskoj gubernii [Review of Saratovskaya Guberniya] (1871-1915). Prilozhenie $k$ Vsepoddannejshemu otchetu [Appendix to Most Humble Report], Saratov.

Obzor Smolenskoj gubernii [Review of Smolenskaya Guberniya] (1871-1915). Prilozhenie $k$ Vsepoddannejshemu otchetu [Appendix to Most Humble Report], Smolensk.

Obzor Tambovskoj gubernii [Review of Tambovskaya Guberniya]. (1871-1911). Prilozhenie $k$ Vsepoddannejshemu otchetu [Appendix to Most Humble Report], Tambov.

Obzor Vologodskoj gubernii [Review of Vologodskaya Guberniya] (1871-1915). Prilozhenie $k$ Vsepoddannejshemu otchetu [Appendix to Most Humble Report], Vologda.

Obzor Vyatskoj gubernii [Review of Viatskaya Guberniya] (1871-1916). Prilozhenie $k$ Vsepoddannejshemu otchetu [Appendix to Most Humble Report], Viatka.

Obzor Yaroslavskoj gubernii [Review of Iaroslavskaya Guberniya] (1872-1915). Prilozhenie $k$ Vsepoddannejshemu otchetu [Appendix to Most Humble Report], Iaroslavl'.

Polnoe sobranie zakonov Rossijskoj Imperii [Comprehensive Collection of the Laws of the Russian Empire] (1911). $3^{\text {rd }}$ Collection. Vol. XXVIII. 1908. Part 1, no 30328, Saint Petersburg: Gosudarstvennaya tipografiya.

Pravilova E.A. (2006) Finansy imperii: Den'gi $i$ vlast'v politike Rossii na natsional'nykh okrainakh, 1801-1917 [The Empire's Finance: Money and Power in Russia's Policy in the National Peripheries, 1801-1917], Moscow: Novoe izdatel'stvo.

Proekt “Dinamika ekonomicheskogo i sotsial'nogo razvitiya Rossii v XIX-nachale XX vv." (2012) [The Project on Dynamics of Russia's Economic and Social Development in 19th - Early 20th Centuries]. Available at: http://www.hist.msu.ru/Dynamics/index.html, accessed 21.04.2021.

Rashin A.G. (1956) Naselenie Rossii za 100 let (1811-1913 gg.): Statisticheskie ocherki [Russia's Population over 100 Years (1811-1913): Statistical Essays], Moscow: Gosudarstvennoe statisticheskoe izdatel'stvo.

Rostow W.W. (1961) Stadii ekonomicheskogo rosta [The Stages of Economic Growth], New-York: Frederick A. Praeger Publishers.

Rozhdestvenskij S.V. (comp.) (1902) Istoricheskij obzor deiatel'nosti Ministerstva narodnogo prosveshcheniya: 1802-1902 [An Historical Survey of Activities of the Ministry of Public Education], Saint Petersburg: Ministry of Public Education.

Sbornik postanovlenij po Ministerstvu Narodnogo Prosveshcheniya [Collection of Regulations by the Ministry of Public Enlightenment] (1875). $2^{\text {nd }} \mathrm{ed}$. Vol. 1: Tsarstvovanie imperatora Aleksandra I [The Reign of Alexander I]. 1802-1825, Saint Petersburg: Tipografiia V.S. Balasheva.

Sharago V.I. (ed.) (1914) Statisticheskij ezhegodnik na 1914 g. God izdanija tretii [Statistical Yearbook for 1914. The Third Year of Publication], Saint Petersburg: Sovet s"ezdov predstavitelej promyshlennosti i torgovli.

Statisticheskij vremennik Rossijskoj imperii (1886) Seriya III. Vypusk 16. Dokhody i raskhody gubernskikh i uezdnykh zemstv za 1883 god [Statistical Annual Book of the Russian Empire. Series III. Issue 16. Receipts and Expenditures of Regional and Local Self-governments in 1883], Saint Petersburg.

Strumilin S.G. (1954) Istoriya chernoj metallurgii v SSSR [History of Black Metallurgy in the USSR]. Vol. 1, Moscow: Izdatelstvo Akademii Nauk SSSR.

Suvorov A.V., Suvorov N.V., Grebennikov V.G., Ivanov V.N., Balashova E.E., Treshchina S.V., Bondarenko N.V., Krasil'nikova M.D., Boldov O.N. (2016) Chelovecheskij kapital kak faktor sotsial'no-ekonomicheskogo razvitiya Rossii [Human Capital as a Factor of Russia's Socio-economic Development], Saint Petersburg: Nestor-Istoriya.

Tabellini G. (2010) Culture and Institutions: Economic Development in the Regions of Europe. Journal of the European Economic Association, vol. 8, no 4, pp. 677-716. DOI: $10.1111 / \mathrm{j} .1542-4774.2010 . t b 00537 . \mathrm{x}$ 
Turner C. Tamura R., Mulholland S. E., Baier S. (2007) Education and Income of the States of the United States: 1840-2000. Journal of Economic Growth, vol. 12, no 2, pp. 101-158.

Turner C., Tamura, R., Mulholland S., Baier S. (2013) How Important Are Human Capital, Physical Capital and Total Factor Productivity for Determining State Economic Growth in the United States, 1840-2000? Journal of Economic Growth, Springer, vol. 18, no 4, pp. 319-371.

Van Leeuwen B., Didenko D., Földvári P. (2015) Inspiration versus Perspiration in Economic Development of the Former Soviet Union and China (ca. 1920-2010). Economics of Transition, vol. 23, no 1, pp. 213-246.

Van Leeuwen B., Van Leeuwen-Li J., Foldvari P. (2017) Human Capital in Republican and New China: Regional and Long-term Trends. Economic History of Developing Regions, vol. 32, no 1 , pp. 1-36.

Volkov E.Z. (1930) Dinamika narodonaseleniya SSSR za 80 let [Dynamics of the USSR Population over 80 Years], Moscow: Gosizdat.

Yartsev A.A. (2015) Gubernatorskie otchety kak istochnik po istorii samoupravleniya v Rossijskoj imperii [Governor's Reports as a Source for Historical Studies in Self-government in the Russian Empire]. Kaliningradskie arkhivy, no 12, pp. 16-25.

Yasnopol'skij N.P. (1897) Prilozheniya $k$ issledovaniyu o geograficheskom raspredelenii gosudarstvennykh raskhodov v Rossii: Statisticheskie tablitsy, kartogrammy i diagrammy [Appendices to the Study on the Geographical Distribution of the Government Expenditures in Russia: Statistical Tables, Maps and Charts]. Part 2, Kiev: Tipografiia Kievskogo Imperatorskogo universiteta. 